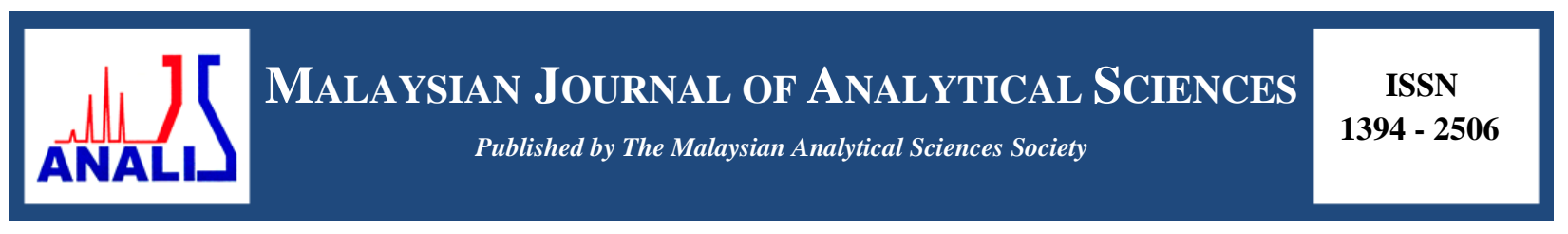

\title{
SYNTHESIS AND CHARACTERIZATION OF SILICA-SILVER CORE-SHELL NANOPARTICLES
}

\author{
(Sintesis dan Pencirian Silika-Perak Nanopartikel Teras-Cengkerang) \\ Nur Kamilah Mohd, Wan Mohd Afiq Wan Mohd Khalik, Alyza A. Azmi* \\ School of Marine and Environmental Sciences, \\ Universiti Malaysia Terengganu, 21030 Kuala Nerus, Terengganu, Malaysia \\ *Corresponding author: alyza.azzura@umt.edu.my
}

Received: 10 February 2019; Accepted: 30 March 2019

\begin{abstract}
Silica-silver core-shell nanoparticles have received tremendous interests in various applications compared to the bare silver nanoparticles due to several important features such as exhibit higher surface area, the existence of a synergistic effect between the core and the shell, stabilize silver nanoparticles against aggregation, and easily control their properties by the changing shell structure and shell geometry. Due to this significance, this study was conducted to synthesis and characterization of silica-silver core-shell nanoparticles using the facile method without any surface modification needed. In the synthesis route, silica particles have been synthesis based on the Stöber method. The deposition of nanoscales silver layer on silica surface mainly involves the electrostatic attraction between $\left[\mathrm{Ag}\left(\mathrm{NH}_{3}\right)_{2}\right]^{+}$ions and silanol groups, and the addition of polyvinylpyrrolidone (PVP) has been acted as a reducing agent and stabilizing agent. UV-Vis spectroscopy evidenced the absorption of surface plasmon resonance (SPR) of silver nanoparticles in the range 380-450 $\mathrm{nm}$. The crystallinity of silica-silver core-shell nanoparticles showed the facecentered cubic (fcc) structure by X-ray powder diffraction (XRD) analysis. The spherical shape of silica particles with an average $200-220 \mathrm{~nm}$ in size has been determined using scanning electron microscope (SEM). The high resolution-transmission electron microscope (HR-TEM) images visualized the successful formation of spherical silver nanoparticles on the silica surface with the average of size 10-40 $\mathrm{nm}$. X-ray photoelectron spectroscopy analysis revealed the elemental compositions exist in the silica-silver core-shell nanoparticles. The synthesized silica-silver core-shell nanoparticles will be used as a potential catalyst in dye treatment application in the future work.
\end{abstract}

Keywords: core-shell, nanoparticles, silica-silver core-shell, deposited, Stöber method

\begin{abstract}
Abstrak
Silika-perak nanopartikel teras-cengkerang telah menarik minat yang besar dalam pelbagai aplikasi berbanding dengan nanopartikel perak disebabkan oleh beberapa kelebihan seperti permukaan kawasannya lebih tinggi, kewujudan kesan sinergi di antara teras dan cengkerang, mengelakkan pengumpulan nanopartikel perak dan memudahkan untuk mengawal ciri-ciri yang dikendaki dalam nanopartikel teras-cengkerang dengan mengubah morfologi dan geometri partikel cengkerang. Sintesis dan pencirian silika-perak nanopartikel teras-cengkerang telah dilakukan tanpa sebarang pengubahsuaian terhadap permukaan partikel. Proses sintesis melibatkan penghasilan zarah silika menggunakan kaedah Stöber. Pemendapan lapisan perak nano pada permukaan silika melibatkan tarikan elektrostatik antara kumpulan ion $\left[\mathrm{Ag}\left(\mathrm{NH}_{3}\right)_{2}\right]^{+}$dan kumpulan silanol, dan penambahan polivinilpirolidon (PVP) akan bertindak sebagai agen penurunan dan agen penstabilan. Pencirian silika-perak nanopartikel terascengkerang menggunakan spektroskopi ultra lembayung tampak (UV-Vis) telah menunjukkan penyerapan resonansi plasmon permukaan (SPR) nanopartikel perak dalam lingkungan 380 - $450 \mathrm{~nm}$. Kehabluran silika-perak nanopartikel teras-cengkerang menunjukkan struktur berpusatkan kubik berpusat (fcc) dengan menggunakan pembelauan sinar-X (XRD). Zarah silika berbentuk sfera dengan saiz $200 \mathrm{~nm}$ ditentukan dengan menggunakan mikroskop imbasan elektron (SEM). Saiz perak yang telah didepositkan pada permukaan silika telah diukur menggunakan mikroskop transmisi elektron beresolusi tinggi (HR-TEM) dengan ukuran 10-40 nm. Analisis spektrometer fotoelektron sinar-X (XPS) telah mendedahkan komposisi unsur yang ada di
\end{abstract}




\section{Nur Kamilah et al: $\quad$ SYNTHESIS AND CHARACTERIZATION OF SILICA-SILVER CORE-SHELL NANOPARTICLES}

dalam silika-perak nanopartikel teras-cengkerang. Nanopartikel teras-petala silika-perak akan digunakan sebagai potensi rawatan pewarna pada masa akan datang.

Kata kunci: teras-cengkerang, nanopartikel, silika-perak nanopartikel teras-cengkerang, deposit, kaedah Stöber

\section{Introduction}

Metal core-shell nanoparticles have received tremendous interest in various fields because of the potential of combining the advantageous properties of two materials into a single constructional unit. It has been applied in such electronic, biomedical, and environmental field as an antimicrobial agent, drug carrier, or catalyst for pollutants removal. Comparing to the traditional nanoparticles, the combination of the two types of materials as a core and a shell into a single structure provides long term stability and flexibility in surface functionalization. Nischala and the co-workers stated that the core-shell nanoparticles offer several advantages such as high surface area, which increase their performance in any applied fields [1]. It also provides an advanced active interface and a potential synergistic effect between the core and shell to gain higher efficiency, especially in catalytic application [2].

The development of core-shell nanomaterials is expanding drastically driven by the demand in industry and society. Up to now, the construction and characterization of various core-shell nanomaterials have been published. For instance, the $\mathrm{BaTiO}_{3}-\mathrm{SiO}_{2}$ core-shell nanoparticles have been successfully enhancing the energy storage capacity [3], $\mathrm{CdS}-\mathrm{TiO}_{2}$ as a promising candidate for visible light active removal of dye pollutants in water [4], $\mathrm{Fe}_{3} \mathrm{O}_{4}-\mathrm{Au}$ as a nontoxic and biocompatible material for biomedical targeted drug delivery [5], $\mathrm{Ag}-\mathrm{TiO}_{2}$ as a gas sensing material [6], Fe-Ni as a catalyst for hydrogen generation [7] and $\mathrm{CeO}_{2}-\mathrm{TiO}_{2}$ as a catalyst for photoreduction of carbon dioxide under visible light irradiation [8]. Among these materials, the preparation of silica-based core-shell material has attracted our interest of study.

Silica $\left(\mathrm{SiO}_{2}\right)$ compound has been explored as a core material in the development of core-shell nanostructures. $\mathrm{SiO} \mathrm{O}_{2}$ can be considered cheap and green materials, which can be found abundantly in plant husk and leaves. For example from the sugarcane bagasse [9], rice husk [10], sugar beet bagasse [11], sorghum leaves [12] and lotus flower leaves [13]. Thus, from an economic point of view, the utilization of $\mathrm{SiO}_{2}$ as a core material may reduce the overall production cost of the metal-core-shell nanostructure. It also exhibits characteristics such as high chemical and thermal stabilities, chemical inertness, large surface areas, good compatibilities with other material and better stability against coagulation [14]. A large number of silanol ( $\mathrm{Si}-\mathrm{OH}$ ) groups on the surface of $\mathrm{SiO}_{2}$ consist of hydrophilic characteristics, which provides a strong interaction with any polar compound through hydrogen bonding interactions [15]. The $\mathrm{SiO}_{2}$ compound can be synthesized following various methods such as flame synthesis [16], microemulsion modified technique [17] and extraction precipitation [18]. However, these methods suffer certain limitations including costly, produced non-uniform of the particle size and morphology, and the difficulty to remove the surfactant in the end product. Therefore, Stöber method has been adopted as it is easy to scale up the particle size and possibility effortless to transfer into the aqueous solution [19].

$\mathrm{SiO}_{2}$ has been used as substrate materials for the immobilization of precious metal such as $\mathrm{TiO}_{2}$ [20], Au [21], and $\mathrm{Ni}$ [22]. The bare metal nanoparticles are active and have a higher tendency to coalesce in solution form due to the van der Waals forces and high surface energy. In our study, the deposition of silver nanoparticles (Ag-Nps) on the $\mathrm{SiO}_{2}$ core surfaces has been developed for the potential application in catalytic activities.

Herein, silica-silver, $\left(\mathrm{SiO}_{2}-\mathrm{Ag}\right)$ core-shell nanoparticles were prepared with the addition of polyvinylpyrrolidone as a reducing and stabilizing agent. There were no linkers or metals such as tin(II) chloride, palladium, gold and organosilane added to activate $\mathrm{SiO}_{2}$ particles prior to load Ag-Nps to the surface of the core. The addition of any linkers will be lead to the existence of impurities in the end product of $\mathrm{SiO}_{2}-\mathrm{Ag}$ core-shell nanoparticles. Different concentration of ammoniacal silver nitrate solution which is a source of Ag ions was employed to control the coverage of $\mathrm{Ag}-\mathrm{Nps}$ on the $\mathrm{SiO}_{2}$ surface. The presences of surface plasmon resonance of Ag-Nps have been determined by UV-Vis spectroscopy. The crystalline natures were evidenced by X-ray powder diffraction (XRD), while the elemental compositions of $\mathrm{SiO}_{2}-\mathrm{Ag}$ were evaluated by X-ray photoelectron spectroscopy (XPS). The size 
and morphology of core-shell structure were visualized using scanning electron microscope (SEM) and high resolution-transmission electron microscope (HR-TEM).

\section{Materials}

\section{Materials and Methods}

Absolute ethanol (EMSURE, analytical grade), ethanol (R\&M chemical, 95\%, analytical grade), ammonium hydroxide (R\&M Chemical, 25\%, analytical grade), tetraethyl orthosilicate (Sigma-Aldrich, 98\%, reagent grade), silver nitrate (Bendosen, analytical reagent), sodium hydroxide (R\&M Chemical, analytical reagent), polyvinylpyrrolidone (Sigma Aldrich, average molecular weight 40,000). Deionized water from water purification system Milli-Q integral water system was used throughout the experiment (Merck, $18 \Omega \mathrm{M}$ ).

\section{Synthesis of silica particles}

$\mathrm{SiO}_{2}$ particles have been synthesized following the Stöber method. Absolute ethanol $(30 \mathrm{~mL})$, water $(6 \mathrm{~mL})$, ammonium hydroxide solution $(1.5 \mathrm{~mL})$ were mixed in a round-bottom flask at the room temperature under continuously stirring (1000 rpm) for 30 minutes. Next, $2.4 \mathrm{~mL}$ of tetraethyl orthosilicate was added and left for 3 hours and the resulting particles were centrifuged at $3600 \mathrm{rpm}$ for 20 minutes. The products were washed for at least 3 times with deionized water and ethanol to separate the particles. The obtained $\mathrm{SiO}_{2}$ then were dispersed in absolute ethanol for subsequently used.

\section{Synthesis of silica-silver core-shell nanoparticles}

Ammoniacal silver nitrate solution, $\left[\mathrm{Ag}\left(\mathrm{NH}_{3}\right)_{2}\right]^{+}$was freshly prepared throughout the experiment. The silver nitrate solution was prepared by dissolving silver nitrate into $10 \mathrm{~mL}$ of deionized water. Next, $1 \mathrm{~mL}$ of sodium hydroxide $(0.1 \mathrm{M})$ was added while slowly swirling. The formation of silver oxide, $\operatorname{Ag}_{2} \mathrm{O}$ as the main product caused a color change from colorless to yellowish-brown. The chemical equation for the formation of $\mathrm{Ag}_{2} \mathrm{O}$ shown in equation 1 .

$$
2 \mathrm{AgNO}_{3}+2 \mathrm{NaOH} \longrightarrow \mathrm{Ag}_{2} \mathrm{O}+2 \mathrm{NaNO}_{3}+\mathrm{H}_{2} \mathrm{O}
$$

Next, $4 \mathrm{~mL}$ of aqueous ammonia was added slowly to the $\mathrm{Ag}_{2} \mathrm{O}$ solution. The color of the solution turned clear indicates the formation of ammoniacal silver nitrate solution and the chemical equation is shown in Equation 2.

$$
\mathrm{Ag}_{2} \mathrm{O}+4 \mathrm{NH}_{3}+2 \mathrm{NaNO}_{3}+\mathrm{H}_{2} \mathrm{O} \longrightarrow 2\left[\mathrm{Ag}\left(\mathrm{NH}_{3}\right)_{2}\right] \mathrm{NO}_{3}+2 \mathrm{NaOH}
$$

For the preparation of $\mathrm{SiO}_{2}-\mathrm{Ag}$ core-shell nanoparticles, $5 \mathrm{~g}$ of the prepared $\mathrm{SiO}_{2}$ dispersion was added into $10 \mathrm{~mL}$ of $\left[\mathrm{Ag}\left(\mathrm{NH}_{3}\right)_{2}\right]^{+}$solution under continuous stirring for at a speed $700 \mathrm{rpm}$ for 2 hours at the room temperature. This process allows an electrostatic attraction between $\left[\mathrm{Ag}\left(\mathrm{NH}_{3}\right)_{2}\right]^{+}$ions with the hydroxyl groups on the surface of silica particles. After 2 hours, PVP $\left(5 \times 10^{-4} \mathrm{moL}^{-1}\right)$ was added to the solution, followed by stir and reflux at $75^{\circ} \mathrm{C}$ for 8 hours. The color of the solution changed darker, which indicates the growth of the outer silver nanoshell on the $\mathrm{SiO}_{2}$ core surfaces. The solution was then centrifuged at 3600 rom for 20 minutes to remove excess $\mathrm{Ag}^{+}$ions, washed with ethanol and deionized water. The precipitate was redispersed in the deionized water prior to further characterization.

\section{Characterization}

$\mathrm{SiO}_{2}-\mathrm{Ag}$ core-shell nanoparticles were characterized using standard spectroscopy and microscopy techniques. Spectroscopy study was carried out using UV-Vis spectrophotometer (UV-Shidmazu model 1800 with software UV Probe 2.43) in the wavenumber range from 200 to $800 \mathrm{~nm}$. An amount of $0.01 \mathrm{~g}$ of the sample was added to $100 \mathrm{~mL}$ of deionized water and sonicated for 20 minutes to form a disperse solution. The samples were placed in a quartz cuvette, and the UV spectrum was recorded. The elemental composition of $\mathrm{SiO}_{2}-\mathrm{Ag}$ core-shell nanoparticles was determined using X-ray photoelectron spectroscopy (XPS). It's were carried out with AXIS ULTRADLD (Shimadzu), equipped with $\mathrm{Mg} \mathrm{K} \alpha(\mathrm{hv}=1253.6 \mathrm{eV}$ ) X-ray source. The binding energies were referenced to the $\mathrm{C} 1 \mathrm{~s}$ peak energy at $284.6 \mathrm{eV}$. 
The morphology of $\mathrm{SiO}_{2}$ particles was observed using a scanning electron microscope (SEM, JEOL model 6360F). A drop of dispersion and also thin film was placed on a sample stub, dried, then sputter-coated with gold prior to examination in order to minimize charging effects. It was operated at an accelerating voltage of 10 and $15 \mathrm{kV}$ with 15,000 magnifications. The morphologies and size of the $\mathrm{SiO}_{2}-\mathrm{Ag}$ core-shell nanoparticles were observed using high transmission electron microscope (TECNAI G2 20 S-TWIN, with FEI), $200 \mathrm{kV}$. An amount of $0.001 \mathrm{~g}$ of samples was dispersed with $20 \mathrm{~mL}$ of water and ultra-sonicated for 20 minutes. Then, it was dried on the carboncoated copper grids before measurement. The structural characterizations of prepared samples were carried out using X-ray powder diffraction (XRD) analyzer ( $\mathrm{X}^{\prime}$ Pert Pro). X-ray diffractometer with $\mathrm{Cu} \mathrm{K} \alpha$ radiation $(\lambda=1.54056 \mathrm{~A})$ at a scanning rate of 0.301 degrees per second in the range $2 \Theta$ ranging from $10^{\circ}$ to $80^{\circ}$.

\section{Results and Discussion}

$\mathrm{SiO}_{2}$ - $\mathrm{Ag}$ core-shell nanoparticles were synthesized via the fabrication of $\mathrm{Ag}-\mathrm{Nps}$ on the surface of $\mathrm{SiO}_{2}$ particles with the addition of PVP as a reducing and stabilizing agent. The diagram for complete preparation of the $\mathrm{SiO}_{2}-\mathrm{Ag}$ core-shell nanoparticles is shown in Scheme 1.

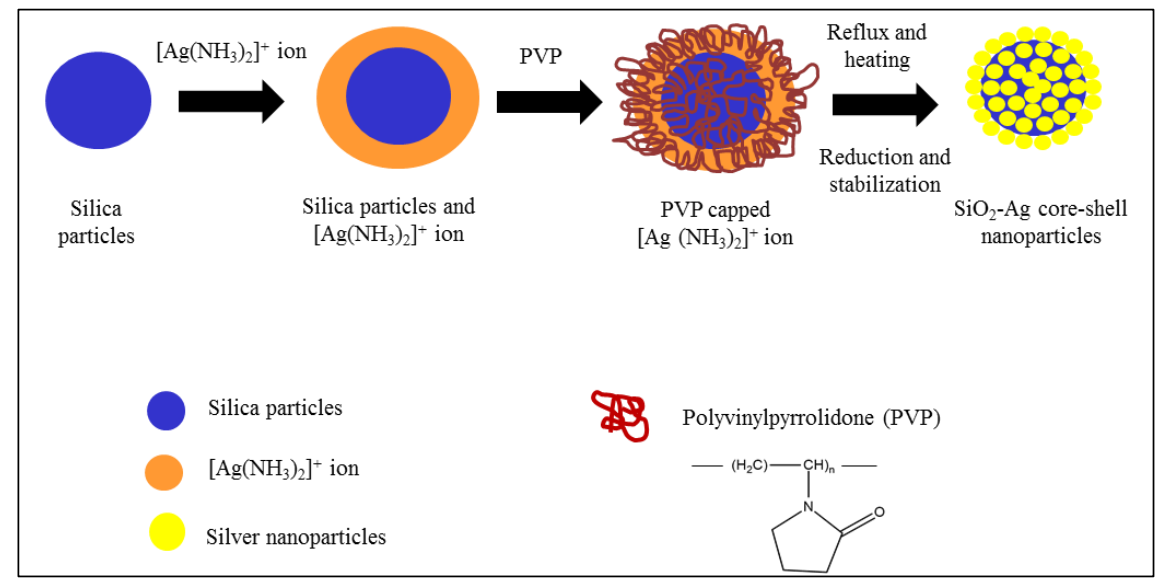

Scheme 1. Schematic representation of the reaction for the synthesis of $\mathrm{SiO}_{2}-\mathrm{Ag}$ core-shell nanoparticles

$\mathrm{SiO}_{2}$ particles were synthesized based on the Stöber method, with the reaction of TEOS in water-alcohol-ammonia solution. Two main reactions involved, which are the formation of the silanol group by hydrolysis process, followed by the formation of the siloxane bridges through a condensation polymerization reaction. The following reaction (equation 3-5) is proposed for the fabrication of $\mathrm{Ag}-\mathrm{Nps}$ on the $\mathrm{SiO}_{2}$ surface:

$$
\begin{aligned}
& (\mathrm{RO})_{3} \text {-Si-OR }+\mathrm{H}_{2} \mathrm{O} \underset{-\mathrm{R}-\mathrm{OH}}{\stackrel{\text { Hydrolysis }}{\longrightarrow}}(\mathrm{RO})_{3}-\mathrm{Si}-\mathrm{OH}+\mathrm{R}-\mathrm{OH} \\
& \left(\mathrm{RO}_{3}\right)-\mathrm{Si}-\mathrm{OH}+(\mathrm{RO})_{3} \text {-Si-OH } \underset{-\mathrm{H}_{2} \mathrm{O}}{\stackrel{\text { Condensation }}{\longrightarrow}}\left(\mathrm{RO}_{3}\right) \text {-Si-O-Si- }\left(\mathrm{RO}_{3}\right)+\mathrm{H}_{2} \mathrm{O} \\
& (\mathrm{RO})_{3} \mathrm{Si}-\mathrm{OH}+\left(\mathrm{RO}_{3}\right)-\mathrm{Si}-\mathrm{OR} \underset{-\mathrm{R}-\mathrm{OH}}{\stackrel{\text { Condensation }}{\longrightarrow}}\left(\mathrm{RO}_{3}\right)-\mathrm{Si}-\mathrm{O}-\mathrm{Si}-\left(\mathrm{OR}_{3}\right)+\mathrm{R}-\mathrm{OH}
\end{aligned}
$$

The formation of $\left[\mathrm{Ag}\left(\mathrm{NH}_{3}\right)_{2}\right]^{+}$as a source of $\mathrm{Ag}^{+}$is based on the complexation of $\mathrm{Ag}$ ions by ammonia hydroxide solution. According to Strzałka and co-workers, the consumption of $\left[\mathrm{Ag}\left(\mathrm{NH}_{3}\right)_{2}\right]^{+}$as a $\mathrm{Ag}$ ion source can be considered as a rapid and easy pathway in the synthesis of $\mathrm{SiO}_{2}$-Ag core-shell nanostructure [23]. The deposition of Ag-Nps on the $\mathrm{SiO}_{2}$ surface is formed based on the activation action of $\left[\mathrm{Ag}\left(\mathrm{NH}_{3}\right)_{2}\right]^{+}$with $\mathrm{SiO}_{2}$ core surfaces. The negatively charged ions of the silanol groups on the $\mathrm{SiO}_{2}$ core surface will attract the $\left[\mathrm{Ag}\left(\mathrm{NH}_{3}\right)_{2}\right]^{+}$ions due to the 
electrostatic attractive interaction. The addition of PVP will reduce the oxidation state number of $\mathrm{Ag}^{+}$, which is from +1 to 0 . PVP also prevent aggregation in the dispersion due to the charge neutralization of the silanol group with $\left[\mathrm{Ag}\left(\mathrm{NH}_{3}\right)_{2}\right]^{+}$ion [24]. The Ostwald ripening phenomenon where the particles in the reaction redissolve and their solvated species growth become larger particles can be avoided as PVP act as a stabilizer in the solution [25].

\section{UV-Visible analysis}

The formation of Ag-Nps loaded on the $\mathrm{SiO}_{2}$ surface was monitored by UV-Vis spectrophotometer. The reduction of $\mathrm{Ag}$ ions (+1) to $\mathrm{Ag}(0)$ metal have been evaluated by recording the absorption spectrum of the $\mathrm{SiO}_{2}-\mathrm{Ag}$ solution in the range of 200-800 $\mathrm{nm}$. The UV-Visible spectra of $\mathrm{SiO}_{2}$ particles and $\mathrm{SiO}_{2}-\mathrm{Ag}$ core-shell nanoparticles at three different concentrations, which are $0.1 \mathrm{M}, 0.2 \mathrm{M}$, and $0.3 \mathrm{M}$ are depicted in Figure 1.

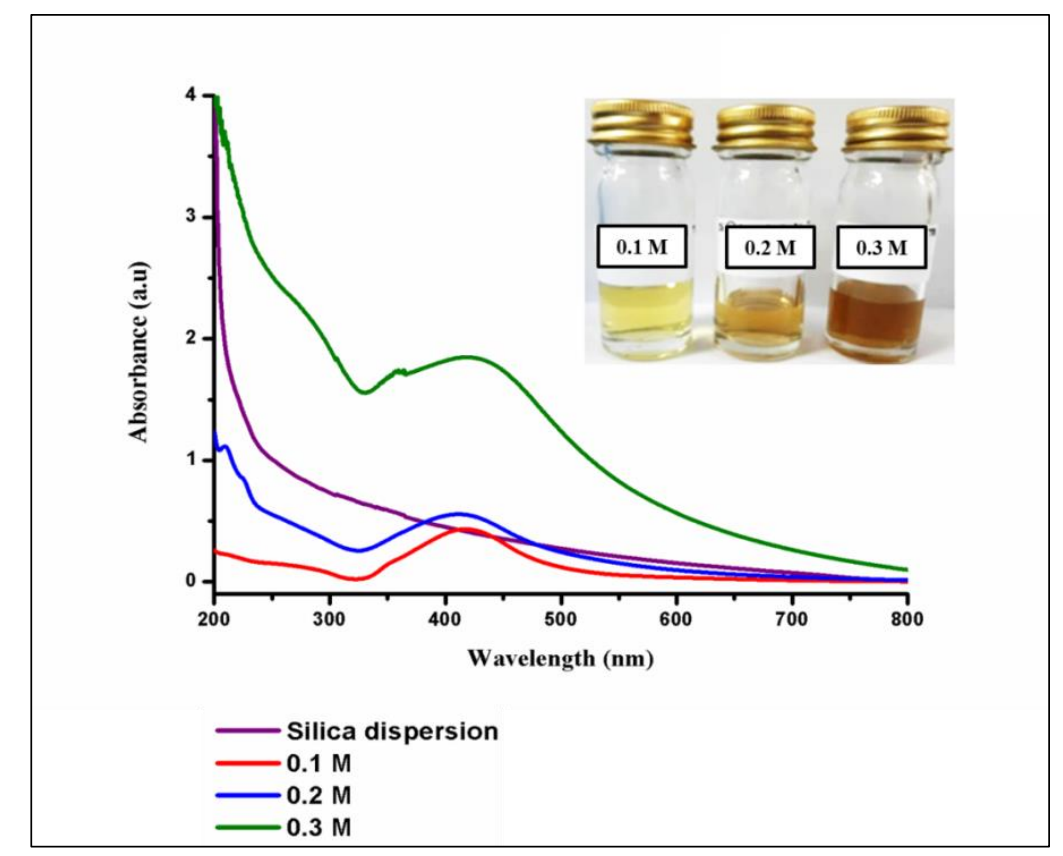

Figure 1. UV-Vis absorption spectra of $\mathrm{SiO}_{2}$ dispersion, $0.1 \mathrm{M}, 0.2 \mathrm{M}$ and $0.3 \mathrm{M}$ of $\mathrm{SiO}_{2}-\mathrm{Ag}$. (Inset shows the image of $0.1 \mathrm{M}, 0.2 \mathrm{M}$ and $0.3 \mathrm{M}$ of $\mathrm{SiO}_{2}-\mathrm{Ag}$ solution)

Optical absorption spectra of Ag loading show the presence of surface plasmon resonance (SPR) effect in the visible region. In this specific wavelength of 380 to $450 \mathrm{~nm}$ range, the incident light can induce a collective oscillation of the electron on the surface of Ag-Nps. This phenomenon is the main reason behind the color change of the $\mathrm{Ag}$ solution from light yellow to brownish as shown in the inset in Figure 1.

The Ag plasmonic properties are strongly correlated with their morphology, such as the size and coverage of the nanoparticles. In this case, the absorption band of SPR shows a red shift and broaden, which is an indication of larger coverage of $\mathrm{Ag}$ nanoparticles on the $\mathrm{SiO}_{2}$ core surfaces as the concentration of $\left[\mathrm{Ag}\left(\mathrm{NH}_{3}\right)^{2+}\right]$ increases. The shift magnitude 1.839 is the highest in $0.3 \mathrm{M}$ concentration, compared to 0.557 and 0.433 for $0.2 \mathrm{M}$ and $0.1 \mathrm{M}$ concentrations, respectively. The research conducted by Tzounis et al. demonstrated that the increase Ag-Nps decorated on the $\mathrm{SiO}_{2}$ spheres enhances the increasing of the absorption peak intensity [26]. On the other hand, no absorbance peak is observed in $\mathrm{UV}-\mathrm{Vis}$ spectra for bare $\mathrm{SiO}_{2}$ particles, supporting that no attachment of $\mathrm{Ag}$ or any impurities on the $\mathrm{SiO}_{2}$ surface.

\section{Electron microscopy analysis}

Figure 2(a) shows the representative SEM micrograph of the monodispersed $\mathrm{SiO}_{2}$ particles. The image reveals the spherical shape of $\mathrm{SiO}_{2}$ particles with a narrow size distribution. The average diameters of $200-220 \mathrm{~nm}$ were 
measured. A smooth edges and bare surface of prepared $\mathrm{SiO}_{2}$ particles has been observed, which is commonly detected in most $\mathrm{SiO}_{2}$ particle preparation using the Stöber method. After Ag adsorption on the $\mathrm{SiO}_{2}$ surface, the surface morphology of the $\mathrm{SiO}_{2}-\mathrm{Ag}$ core-shell nanoparticles roughened (Figure 2b-d). The increase of the $\mathrm{SiO}_{2}-\mathrm{Ag}$ surface roughness was due to the increase of $\mathrm{Ag}$ nanoparticles loaded on the $\mathrm{SiO}_{2}$ core surfaces. This is consistent with the formation of a darker color solution when the concentration of $\left[\mathrm{Ag}\left(\mathrm{NH}_{3}\right)_{2}\right]^{+}$is increased. A study conducted by Ghosh and Paria supporting our argument on the dependency of nanoshell thickness by the reaction concentration [27]. Another study by Postolache and co-workers [28] suggested that the increase of silver nitrate concentration effectively promotes the distribution of $\mathrm{Ag}-\mathrm{Nps}$ onto the surface of $\mathrm{SiO}_{2}$. In addition, there are no $\mathrm{Ag}$ Nps residuals was observed, which indicates a stable Ag-Nps attachment to the $\mathrm{SiO}_{2}$ spheres. Furthermore, it was found that the Ag-Nps were spherical in shape with the size ranges of 8-20 nm for $0.1 \mathrm{M}$ and $0.2 \mathrm{M}$ of $\mathrm{SiO}_{2}-\mathrm{Ag}$, while it ranges $10-40 \mathrm{~nm}$ for $0.3 \mathrm{M}$ of $\mathrm{SiO}_{2}-\mathrm{Ag}$.
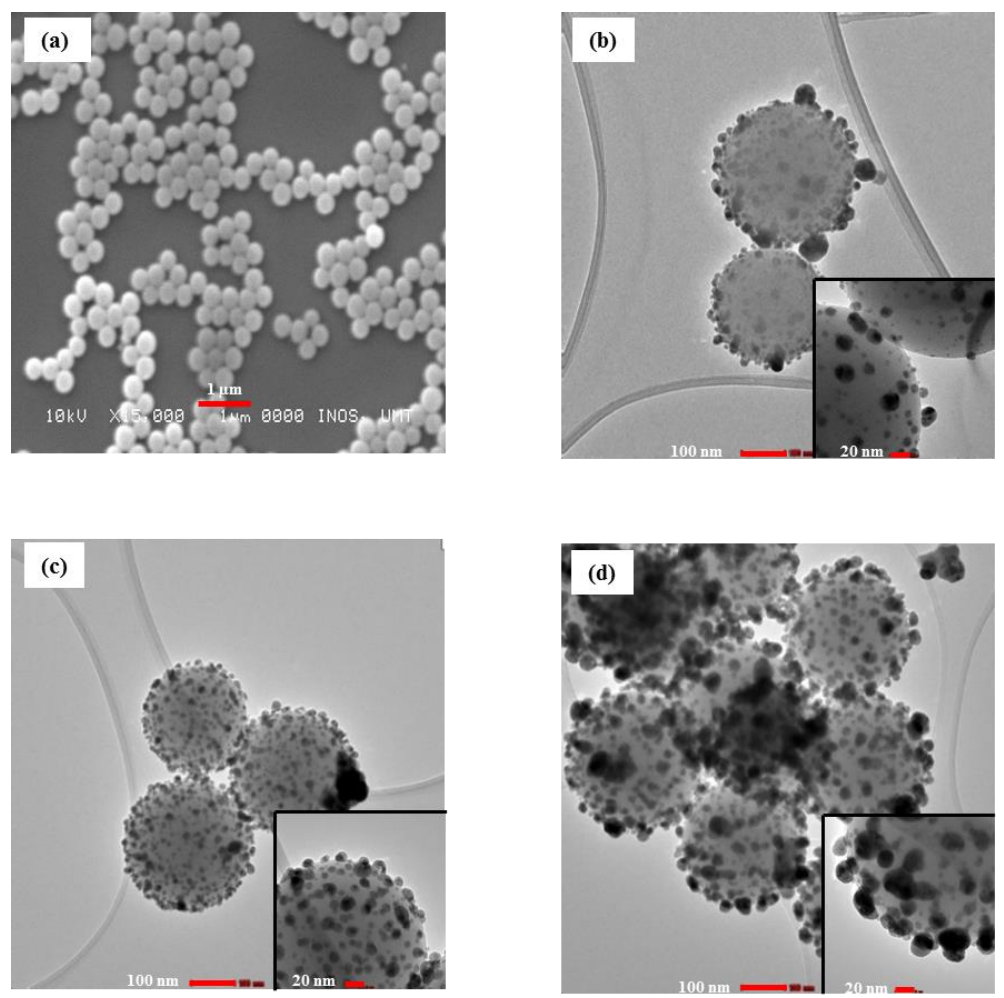

Figure 2. (a) $\mathrm{SEM}$ image of $\mathrm{SiO}_{2}$ particles at 15,000 magnifications, $\mathrm{HR}-\mathrm{TEM}$ images of (b) $0.1 \mathrm{M}$ of $\mathrm{SiO}_{2}$ - $\mathrm{Ag}$, (c) $0.2 \mathrm{M}$ of $\mathrm{SiO}_{2}-\mathrm{Ag}$, (d) $0.3 \mathrm{M}$ of $\mathrm{SiO}_{2}-\mathrm{Ag}$. Lower right sides images show the individual $\mathrm{SiO}_{2}-\mathrm{Ag}$ coreshell HR-TEM images taken of $0.1 \mathrm{M}, 0.2 \mathrm{M}$, and $0.3 \mathrm{M}$ respectively

\section{X-ray powder diffractometer analysis}

Figure 3 illustrated the nature characteristic of the XRD pattern for the $\mathrm{SiO}_{2}$ sphere and $\mathrm{SiO}_{2}-\mathrm{Ag}$ core-shell in various concentrations. In the $\mathrm{SiO}_{2}$ dispersion, broad diffraction peaks in the range of $15^{\circ}-30^{\circ}$ centered at $22^{\circ}$ correspond to their amorphous structure. A typical XRD pattern of the Ag-Nps was found to possess a face cubic centre (fcc) structure. The Bragg reflections at $2 \theta=39.8^{\circ}, 48.5^{\circ}, 63.0^{\circ}$ and $77.50^{\circ}$ can be indexed to the (111),

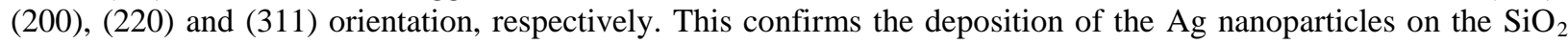
core surfaces. These four peaks were detected which is corresponding to the fcc Ag phase. The fcc pattern of $\mathrm{SiO}_{2^{-}}$ $\mathrm{Ag}$ core-shells fcc pattern is consistent with the previous research [29,30]. There are no major diffraction peaks as consequences of crystallographic impurities were found. The relative intensity of the (111) peak is higher compared to other peaks at each concentration indicates the plane orientation preferential to the surface of $\mathrm{SiO}_{2}$ sphere. 


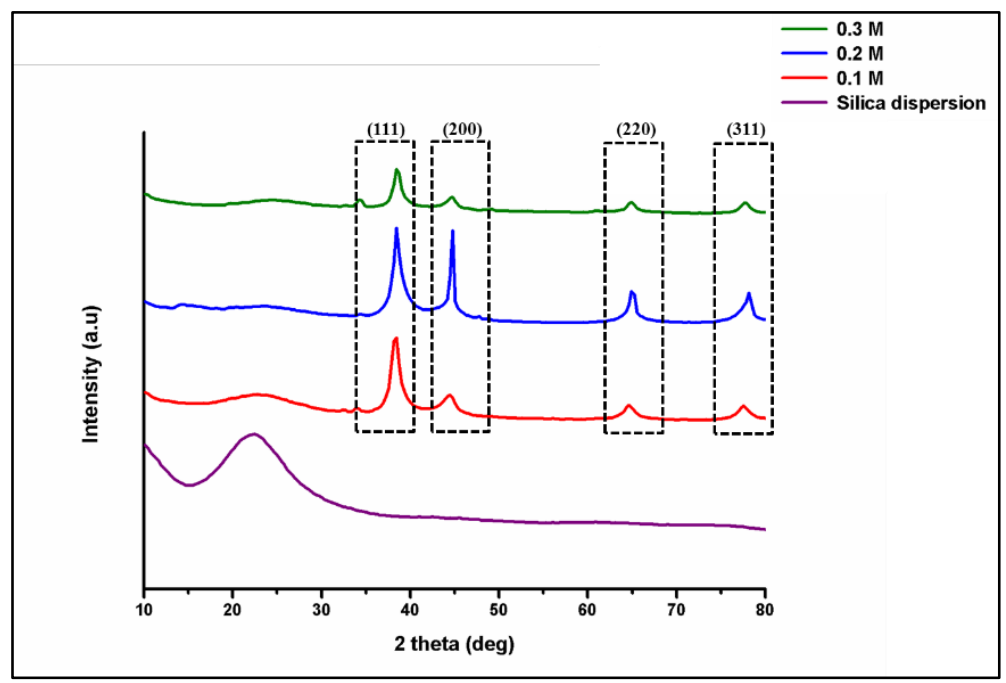

Figure 3. X-ray Powder diffraction patterns of $\mathrm{SiO}_{2}$ particles, $0.1 \mathrm{M}, 0.2 \mathrm{M}$ and $0.3 \mathrm{M}$ of $\mathrm{SiO}_{2}$-Ag core-shell

\section{X-ray photoelectron spectroscopy}

$\mathrm{X}$-ray photoelectron spectra for the $\mathrm{SiO}_{2}-\mathrm{Ag}$ core-shell nanoparticles were acquired from binding energy regions containing peak arising from all elements that should be present in the sample, which are C 1s, Si 2p, Ag 3d, N 1s, and $\mathrm{O} 1 \mathrm{~s}$ as shown in Figure 4. A survey scan in the region of 0 to $1200 \mathrm{eV}$ indicates neither contribution from impurities nor contamination on the surface of the nanoparticles. The presence of carbon and nitrogen element on the surface of nanoparticles is contributing from PVP, which has been used as a reducing and stabilizing agent in the synthesis procedure. This is consistent with the fitting of three atomic species for $\mathrm{C} 1 \mathrm{~s}$ (aromatic carbon, aliphatic and $\mathrm{C}-\mathrm{N} / \mathrm{C}=\mathrm{O}$ species), and a single nitrogen species from PVP [31]. The $\mathrm{Si} 2 \mathrm{p}$ peak centered at $102.3 \mathrm{eV}$ binding energy is attributed to $\mathrm{Si}_{-} \mathrm{O}_{2}$ of the core spheres which correspond closely to the previous literature [32]. The $\mathrm{Ag} 3 \mathrm{~d}$ peaks are found at $366.81 \mathrm{eV}$ and $372.81 \mathrm{eV}$ can be fitted to the typical spin-orbital-splitting pattern of $\mathrm{Ag} 3 \mathrm{~d} 5 / 2$ and $\mathrm{Ag} \mathrm{3d} 3 / 2$, respectively. This confirms the reduction of $\operatorname{Ag}(+1)$ ion to $\operatorname{Ag}(0)$ metal, as appearance of the $\operatorname{Ag} 3 \mathrm{~d}$ peak in XPS is the nature characteristic for zero-oxidation state. This finding was supported by Sakthisabarimoorthi and co-workers on the successful decoration of Ag element [33].

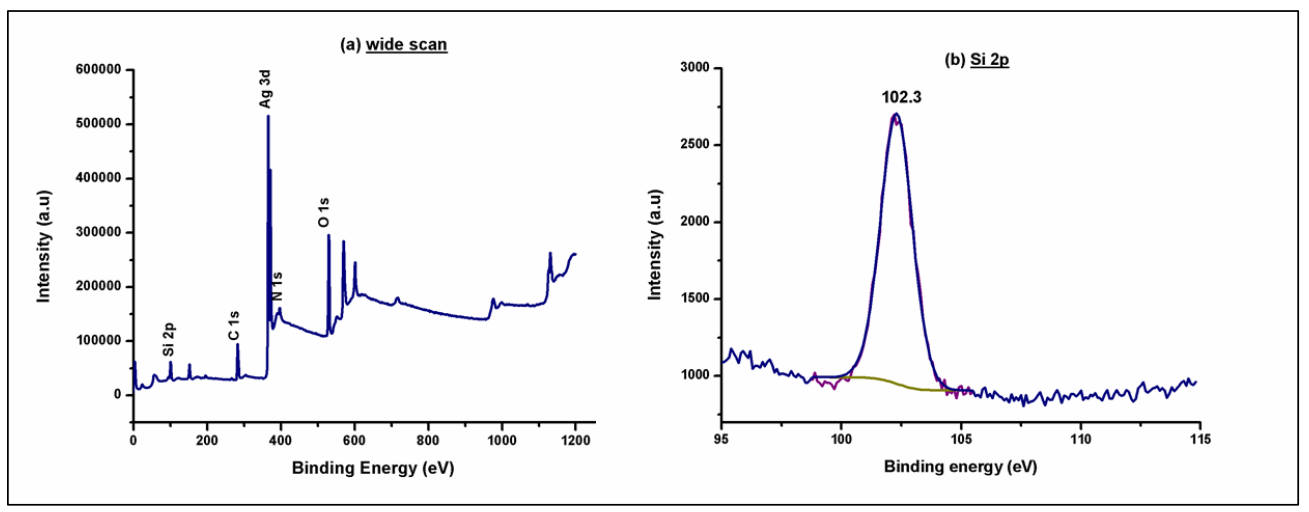



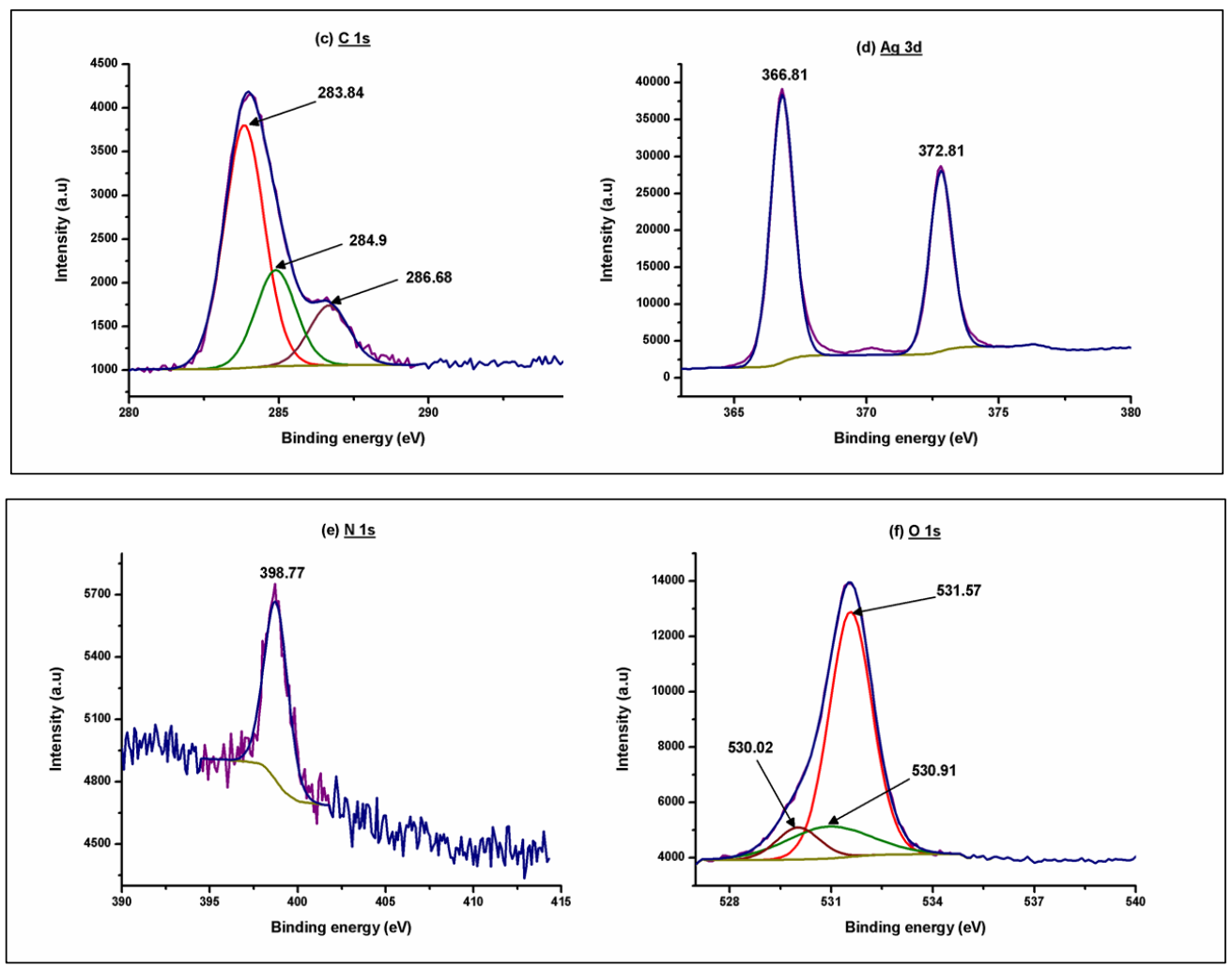

Figure 4. Representative of XPS spectra of (a) wide scan survey, (b) Si 2p, (c) C 1s, (d) Ag 3d, (e) N 1s, and (f) $\mathrm{O} 1 \mathrm{~s}$ for $\mathrm{SiO}_{2}$ - Ag core-shell nanoparticles

\section{Conclusion}

$\mathrm{SiO}_{2}$-Ag core-shell nanoparticles were successfully synthesized with the addition of PVP as a reducing and stabilizing agent without any surface modification needed. The increase of concentration ammoniacal silver nitrate solution leads to the increase in thickness of $\mathrm{Ag}$-Nps loaded on the $\mathrm{SiO}_{2}$ surface. The synthesized $\mathrm{SiO}_{2}-\mathrm{Ag}$ coreshell nanoparticles exhibit the surface plasmon resonance wavelength of 380 to $450 \mathrm{~nm}$ range, which contributed to the existence of Ag-Nps. SEM images visualized the silica particles with $200-220 \mathrm{~nm}$ in size with a spherical shape while HR-TEM images show the Ag-Nps deposited to the surface of $\mathrm{SiO}_{2}$ spheres with the average of size 10-50 $\mathrm{nm}$. X-ray powder diffraction analysis revealed the crystalline nature of Ag-Nps. The elemental composition of $\mathrm{SiO}_{2}-\mathrm{Ag}$ core-shell such as $\mathrm{C} 1 \mathrm{~s}, \mathrm{Si} 2 \mathrm{p}, \mathrm{Ag} 3 \mathrm{~d}, \mathrm{~N} 1 \mathrm{~s}$, and $\mathrm{O} 1 \mathrm{~s}$ were established by X-ray photoelectron spectroscopy analysis. The $\mathrm{SiO}_{2}-\mathrm{Ag}$ core-shell nanoparticles have been successfully synthesized and it is suggested that it can be used as a potential catalyst in the dye degradation process in future studies.

\section{Acknowledgement}

The authors gratefully acknowledge to Central Laboratory, Universiti Malaysia Terengganu for providing research facilities.

\section{References}

1. Nischala, K., Rao, T. N. and Hebalkar, N. (2011). Silica-silver core-shell particles for antibacterial textile application. Colloids and Surfaces B: Biointerfaces, 82(1): 203 - 208.

2. Wang, X., He, B., Hu, Z., Zeng, Z. and Han, S. (2014). Current advances in precious metal core-shell catalyst design. Science and Technology of Advanced Materials, 15(4): 043502. 
3. Xu, C., Su, R., Wang, Z., Wang, Y., Zhang, D., Wang, J., J., Bian, J., Wu, C., Lou, X. and Yang, Y. (2019). Tuning the microstructure of $\mathrm{BaTiO}_{3} @ \mathrm{SiO}_{2}$ core-shell nanoparticles for high energy storage composite ceramics. Journal of Alloys and Compounds, 784: 173 - 181.

4. Kamaruddin, S. and Stephan, D. (2011). The preparation of silica-titania core-shell particles and their impact as an alternative material to pure nano-titania photocatalysts. Catalysis Today, 161(1): 53 - 58.

5. Pati, S. S., Singh, L. H., Oliveira, A. C. and Garg, V. K. (2015). Chitosan functionalized $\mathrm{Fe}_{3} \mathrm{O}_{4} @ \mathrm{Au}$ core-shell nanomaterials for targeted drug delivery. World Academy of Science, Engineering and Technology, International Journal of Chemical, Molecular, Nuclear, Materials and Metallurgical Engineering, 9(6): 670 673.

6. Zhu, Z., Kao, C. T. and Wu, R. J. (2014). A highly sensitive ethanol sensor based on Ag@ $\mathrm{TiO}_{2}$ nanoparticles at room temperature. Applied Surface Science, 320: 348 - 355.

7. Azizi, M. A. H., Dzakaria, N., Isahak, W. N. R. W. and Yarmo, M. A. (2017). Effect of nickel on bimetallic nanoalloy catalyst for hydrogen generation. Malaysian Journal of Analytical Sciences, 21(4): 901 - 906.

8. Abdullah, H., Ismail, N. A., Yaakob, Z., Khan, M. R. and Rahim, S. A. (2017). $\mathrm{CeO}_{2}-\mathrm{TiO}_{2}$ for photoreduction of $\mathrm{Co}_{2}$ to methanol under visible light: effect of ceria loading. Malaysian Journal of Analytical Sciences, 21(1): $166-172$.

9. Mohd, N. K., Wee, N. N. A. N. and Azmi, A. A. (2017). Green synthesis of silica nanoparticles using sugarcane bagasse. In AIP Conference Proceedings, 1885(1): 020123.

10. Ghorbani, F., Sanati, A. M., and Maleki, M. (2015). Production of silica nanoparticles from rice husk as agricultural waste by environmental friendly technique. Environmental Studies of Persian Gulf, 2(1), 56 - 65 .

11. San, N. O., Kurşungöz, C., Tümtaş, Y., Yaşa, Ö., Ortac, B. and Tekinay, T. (2014). Novel one-step synthesis of silica nanoparticles from sugarbeet bagasse by laser ablation and their effects on the growth of freshwater algae culture. Particuology, 17: $29-35$.

12. Qadri, S. B., Gorzkowski, E. P., Imam, M. A., Fliflet, A., Goswami, R., Kim, H., Caldwell, J. D., Klemm, F. and Rath, B. B (2013). Production of nanoscale particles and nanorods of $\mathrm{SiC}$ from sorghum leaves. Industrial Crops and Products, 51: $158-162$.

13. Landage, S. M., Kulkarni, S. G. and Ubarhande, D. P. (2012). Synthesis and application of silica nanoparticles on cotton to impart superhydrophobicity. International Journal of Engineering Research and Technology, 1(5): $1-7$.

14. Kalele, S. A., Ashtaputre, S. S., Hebalkar, N. Y., Gosavi, S. W., Deobagkar, D. N., Deobagkar, D. D. and Kulkarni, S. K. (2005). Optical detection of antibody using silica-silver core-shell particles. Chemical Physics Letters, 404(1-3): 136 - 141.

15. Mansa, R. F., Sipaut, C. S., Rahman, I. A., Yusof, N. S. M. and Jafarzadeh, M. (2016). Preparation of glycinemodified silica nanoparticles for the adsorption of malachite green dye. Journal of Porous Materials, 23(1): 35 $-46$.

16. Chang, H., Park, J. H. and Jang, H. D. (2008). Flame synthesis of silica nanoparticles by adopting two-fluid nozzle spray. Colloids and Surfaces A: Physicochemical and Engineering Aspects, 313: 140 -144.

17. Koźlecki, T., Polowczyk, I., Bastrzyk, A. and Sawiński, W. (2016). Improved synthesis of nanosized silica in water-in-oil microemulsions. Journal of Nanoparticles, 2016: 1 - 9.

18. Monshizadeh, M., Rajabi, M., Ahmadi, M. H. and Mohammadi, V. (2015). Synthesis and characterization of nano $\mathrm{SiO}_{2}$ from rice husk ash by precipitation method. $3^{\text {rd }}$ National Conference on Modern Researches in Chemistry and Chemical Engineering: pp. $1-4$.

19. Gholami, T., Salavati-Niasari, M., Bazarganipour, M. and Noori, E. (2013). Synthesis and characterization of spherical silica nanoparticles by modified Stöber process assisted by organic ligand. Superlattices and Microstructures, 61: 33 - 41 .

20. Kitsou, I., Panagopoulos, P., Maggos, T., Arkas, M. and Tsetsekou, A. (2018). Development of $\mathrm{SiO}_{2} @ \mathrm{TiO}_{2}$ core-shell nanospheres for catalytic applications. Applied Surface Science, 441: 223 - 231.

21. Kandpal, D., Kalele, S. and Kulkarni, S. K. (2007). Synthesis and characterization of silica-gold core-shell $\left(\mathrm{SiO}_{2} @ \mathrm{Au}\right)$ nanoparticles. Pramana, 69(2): 277-283.

22. Gac, W., Zawadzki, W., Słowik, G., Sienkiewicz, A. and Kierys, A. (2018). Nickel catalysts supported on silica microspheres for $\mathrm{CO}_{2}$ methanation. Microporous and Mesoporous Materials, 272: 79 - 91.

23. Zienkiewicz-Strzałka, M., Pasieczna-Patkowska, S., Kozak, M. and Pikus, S. (2013). Silver nanoparticles incorporated onto ordered mesoporous silica from Tollen's reagent. Applied Surface Science, 266: 337 -343. 
24. Jankiewicz, B. J., Jamiola, D., Choma, J. and Jaroniec, M. (2012). Silica-metal core-shell nanostructures. Advances in Colloid and Interface Science, 170(1-2): 28 - 47.

25. Atkins, P., Overton, T., Rourke, J., Weller, M. and Armstrong, F. (2010). Inorganic Chemistry. Oxford. New York : pp. 659.

26. Tzounis, L., Contreras-Caceres, R., Schellkopf, L., Jehnichen, D., Fischer, D., Cai, C., Uhlmann, P. and Stamm, M. (2014). Controlled growth of Ag nanoparticles decorated onto the surface of $\mathrm{SiO}_{2}$ spheres: a nanohybrid system with combined SERS and catalytic properties. RSC Advances, 4(34): 17846 - 17855.

27. Ghosh, C. R. and Paria, S. (2011). Core/shell nanoparticles: Classes, properties, synthesis mechanisms, characterization, and applications. Chemical Reviews, 112(4): 2373 - 2433.

28. Postolache, P., Petrescu, V., Dumitrascu, D. D., Rimbu, C., Vrînceanu, N. and Cipaian, C. R. (2016). Research regarding a correlation core-shell morphology-thermal stability of silica-silver nanoparticles. Chemical Engineering Communications, 203(5): 649 - 659.

29. Din, L. B., Mie, R., Samsudin, M. W., Ahmad, A. and Ibrahim, N. (2015). Biomimetic synthesis of silver nanoparticles using the lichen Ramalina dumeticola and the antibacterial activity. Malaysian Journal of Analytical Sciences, 19(2): $369-376$.

30. Chen, K. H., Pu, Y. C., Chang, K. D., Liang, Y. F., Liu, C. M., Yeh, J. W., Shih, H. C. and Hsu, Y. J. (2012). Ag-nanoparticle-decorated $\mathrm{SiO}_{2}$ nanospheres exhibiting remarkable plasmon-mediated photocatalytic properties. The Journal of Physical Chemistry C, 116(35): 19039 - 19045.

31. Deng, Z., Chen, M. and Wu, L. (2007). Novel method to fabricate $\mathrm{SiO}_{2} / \mathrm{Ag}$ composite spheres and their catalytic, surface-enhanced Raman scattering properties. The Journal of Physical Chemistry C, 111(31): 11692 -11698 .

32. Das, S. K., Khan, M. M. R., Parandhaman, T., Laffir, F., Guha, A. K., Sekaran, G. and Mandal, A. B. (2013). Nano-silica fabricated with silver nanoparticles: antifouling adsorbent for efficient dye removal, effective water disinfection and biofouling control. Nanoscale, 5(12): 5549 - 5560.

33. Sakthisabarimoorthi, A., Dhas, S. M. B. and Jose, M. (2017). Fabrication and nonlinear optical investigations of $\mathrm{SiO}_{2} @ \mathrm{Ag}$ core-shell nanoparticles. Materials Science in Semiconductor Processing, 71: 69 - 75. 